\title{
Comparative Assessment of Physico-chemical Characteristics of Two Grassland Soils Subjected to Different Uses in Delta State, Nigeria
}

\author{
Amukali Ogochukwu' ${ }^{1}$, Obadoni Bernard Onyemaechi ${ }^{2}$, Bariweni Perekibina Anthony ${ }^{3}$, \\ Iwuegbu Elizabeth ${ }^{4}$ \\ ${ }^{1}$ Department of Environmental Management, Niger Delta University, Wilberforce Island, Bayelsa State, Nigeria \\ ${ }^{2}$ Department of Botany, Faculty of Natural Sciences, Ambrose Alli University, Ekpoma, Edo State, Nigeria \\ ${ }^{3}$ Marine Environment and Pollution Control Department, Nigeria Maritime University, Okerenkoko, Delta State, Nigeria \\ ${ }^{4}$ Botany Department, Faculty of Natural Sciences, Delta State University, Abraka, Delta State, Nigeria
}

Email address:

amukaliogo@yahoo.com (A. Ogochukwu)

\section{To cite this article:}

Amukali Ogochukwu, Obadoni Bernard Onyemaechi, Bariweni Perekibina Anthony, Iwuegbu Elizabeth. Comparative Assessment of Physico-chemical Characteristics of Two Grassland Soils Subjected to Different Uses in Delta State, Nigeria. Science Journal of Analytical Chemistry. Vol. 8, No. 4, 2020, pp. 133-137. doi: 10.11648/j.sjac.20200804.12

Received: May 26, 2020; Accepted: June 18, 2020; Published: December 31, 2020

\begin{abstract}
In this study, physico-chemical properties of 2 differentially located grassland soils which were subjected to different economic usages, were assessed. The study was carried out for grassland soils of Ogbole-Ogume (excavation) and Abbi (Cultivation), both in Ndokwa West LGA of Delta State, Nigeria. The soils were collected at the road margin $(0 \mathrm{~m}), 30 \mathrm{~m}$ into the grasslands and $10 \mathrm{~m}$ away from the end of the grasslands at a depth of about $10.30 \mathrm{~m}$ each from the soil surfaces. Soil characteristics as $\mathrm{pH}, \mathrm{Mg}, \mathrm{Ca}, \mathrm{Na}, \mathrm{K}, \mathrm{EC}, \mathrm{CEC}, \mathrm{SO}_{4}, \mathrm{P}, \mathrm{N}$, clay, silt and sand contents were analyzed following standard procedures and methodologies. At margins, soils from Ogbole-Ogume and Abbi contained $94.5 \%$ and $91.0 \%$ sand; at $30 \mathrm{~m}$ into the grasslands, both were $93.0 \%$ sand while at $10 \mathrm{~m}$ beyond the grassland soils, $93.0 \%$ and $90.0 \%$ sand were recorded for Ogbole-Ogume and Abbi, respectively. Comparatively, physico-chemical parameters investigated in this study showed variations between both sampled sites as parameters like $\mathrm{pH}, \mathrm{Mg}, \mathrm{Ca}, \mathrm{K}, \mathrm{CEC}, \mathrm{P}$ and $\mathrm{N}$ were generally higher in Abbi than in Ogbole-Ogume grassland soils. This clearly indicated that crop cultivation at Abbi grassland soils must have significantly impacted more on the physico-chemical properties of the soils than excavation activities as practiced at Ogbole-Ogume grassland soils. This has strong indications for food security and environmental health.
\end{abstract}

Keywords: Comparative Analyses, Grassland Soils, Physico-Chemical Properties.

\section{Introduction}

Generally, soils constitute significant portions of the solid parts of the earth crust upon which many plants grow. Soil could be defined as the portion of the earth's crust formed from the decomposition of rocks and minerals, through physical, chemical and biotic factors and in which the roots of plants grow [1]. Soil is the upper layer of the ground which is useful for supporting life [2]. The formation of soil has been described to be a continuous and time-dependent process that may require hundreds and thousands of years to reach a stage where the type of soil evolved usually attains equilibrium with the surrounding conditions [1]. A number of factors control or regulate soil formation; climate, nature of parent materials, vegetation, topography and time [2].

Grasslands are thought to have deep soils that are very nutrient-rich because of the amounts of plant tissues (biomass) that die-off and are usually added to the soil through decomposition every year [3]. Grassland soils present a unique soil type with distinct characteristics from other soil types. It has been opined that dry bulk density remains a most appropriate index for describing the structural quality of soils [4]. Grasslands occur naturally in all continents of the world, except Antarctica [3]. In certain conditions, grasslands, have due to human influences, 
replaced some natural vegetations [Ibid, 3]. Grasslands (greenwards) are said to be characteristic areas of vegetation where the vegetation is predominantly dominated by grasses along with other non-woody plants [4]. The dominant plants could be perennial [5] or annual [6] species. Depending on the geographical region of the world where they are found, prevailing microclimatic conditions could help influence the characteristic floral diversity and distributional patterns in grasslands. For instance, a study conducted in 2009 in grasslands of two Niger Delta states (Edo \& Delta) surveyed flora of 18 and 28 grasslands in Edo and Delta States of Nigeria and the authors encountered $29.1 \%$ of the plants as grasses, trees $(25.5 \%)$, herbs $(21.8 \%)$, shrubs (16.4\%), creepers $(5.5 \%)$, and sedges $(1.8 \%)$ in Edo State [7]. On the other hand, 48 taxa distributed into 21 families were encountered in Delta State, Nigeria and based on habits, grasses were $29.2 \%$, trees $(18.8 \%)$, herbs $(18.8 \%)$, sedges (16.7\%), shrubs $(10.4 \%)$, ferns $(4.2 \%)$ and creepers $(2.1 \%)$, respectively, and both zones were observed to have shown similar Simpson's index of diversity of 0.97 while Sorensen's similarity index was found to be $15.2 \%$ [Ibid, 7].

Edaphic grasslands, as opposed to other forms of grasslands are those that are caused by predisposing soil conditions and are not entirely maintained by fire and this can occur on hills or ridges with shallow soils, or in valleys where the clay soils become water-logged during wet weather [8]. Edaphic grasslands in Delta State, Nigeria, could be flooded as in Ogbole-Ogume where the soil is practically wet/flooded for most of the times of the year or dry as seen in Aghalope, Abbi and a host of other geographical locations within and outside the State [7]. Furthermore, it has been opined that no valid scientific reason has been advanced for the existence of grasslands except incoherent myths [Ibid, 7].

Furthermore, it is quite surprising to observe that grasslands in most cases share boundaries with other vegetations like the rain forest vegetation and are subjected to almost the same impacts of the vagaries of weather, like temperature, sunshine, rainfall, relative humidity, dry periods, etc, yet they have different vegetational characteristics or ecological biomes from neighboring geographical areas. Anomalies observed with respect to distributional patterns of soils and different plants within grasslands as they affect soil physico-chemical characteristics formed the basis for this study. Thus, efforts were made to investigate two grassland soils; one in Ogbole-Ogume with wet soil and another in Abbi with dry soils, with a view to establishing the influences of anthropogenic activities on the soil's physico-chemical characteristics and the results compared with those obtained elsewhere in the world.

\section{Methodology}

This present study was carried out on 2 grassland soils in Delta State, Nigeria (Ogbole-Ogume \& Abbi). OgboleOgume lies at latitude $5^{\circ} 49$ North of the equator and longitude $6^{\circ} 19^{3}$ East of the Greenwich Meridian while Abbi is at $5^{\circ} 49^{\prime}$ North of the equator and longitude $6^{\circ} 20^{3}$ East of the Greenwich Meridian.

Soil samples were collected from different locations within the two grasslands with the aid of an auger and a cutlass. The cutlass was first used to clear grasses within portions to pave way for wasy soil collection before the auger was pierced into the soil at an average depth of about $10.30 \mathrm{~cm}$ from the surface of the soil. Samples were taken from the margin $(0 \mathrm{~m}), 30 \mathrm{~m}$ into both grasslands and $10 \mathrm{~m}$ away from the boundaries of both grasslands. Table 1 below showed characteristics of the sampled soils.

Table 1. Showing the Characteristics of the study sites.

\begin{tabular}{lllll}
\hline S/No. & Location & Topography & Drainage & Use \\
\hline 1 & Ogbole Ogume & Flat & Drained & Source of sand for building \\
2 & Ogbole Ogume & Flat & Well drained & Source of sand for building \\
3 & Ogbole Ogume & Flat & Drained & Source of sand for building \\
4 & Abbi & Flat & Drained & Cultivation \\
5 & Abbi & Flat & Drained & Cultivation \\
6 & Abbi & Flat & Drained & Cultivation \\
\hline
\end{tabular}

The soil samples earlier collected were mixed thoroughly to form a homogenous mixture and labeled appropriately. Each mixture was air-dried and sieved through a $2 \mathrm{~mm}$ sieve before being used for the analysis. The particle size analysis of the soil samples was determined using the hydrometer method [9]. Following this proceedure, 51.0g of air-dried soil was passed through a $2.0 \mathrm{~mm}$ sieve and transferred to a mixshake mix-cup. 50cc of 50\% Sodium hexametaphosphate with $100 \mathrm{cc}$ distilled water and stirred for a few minutes before being allowed to settle. Within the multi-mix machine, stirring was continued on the soil suspension for 15 minutes before the suspension was further transferred from the cup to the glancylinder. The hydrometer was inserted into the cylinder and the hydrometer reading taken [Ibid, 9].
The soil $\mathrm{pH}$ was determined at a ratio of 1:1 in water/soil. $20.0 \mathrm{~g}$ of air-dried soil which had earlier passed through the $2.0 \mathrm{~mm}$ sieve was poured into a $50 \mathrm{ml}$ beaker, then, $20 \mathrm{ml}$ of distilled water added and allowed to stand for 30 minutes before stirring with a glass rod. Then, the electrode of the $\mathrm{pH}$ meter was inserted into the part suspension and the $\mathrm{pH}$ reading taken [10]. Total Nitrogen was determined by the Means-Kjeldehl method where $10.0 \mathrm{~g}$ of soil sample was measured and put into a dry $500 \mathrm{ml}$ Macro-Kjeldehl flask and $20 \mathrm{ml}$ of distilled water added. The flask was swirled for a few minutes and allowed to stand. Mercury catalyst was added with $1 \mathrm{mg}$ of $\mathrm{K}_{2} \mathrm{SO}_{4}$, then $30 \mathrm{ml}$ of $\mathrm{H}_{2} \mathrm{SO}_{4}$ added through automatic pipette and the flask heated cautiously at low temperature on the digestion stand. After cooling $100 \mathrm{~m} / \mathrm{g}$ 
distilled water was added before being transferred to another clean Macro-Kjeldehl flask $(750 \mathrm{ml})$, and $50 \mathrm{ml} \mathrm{H}_{3} \mathrm{BO}_{4}$ indicator solution added into a $500 \mathrm{ml}$ solemn-eyes flask distillation apparatus. Thus, $150 \mathrm{ml}$ of $10 \% \mathrm{NaOH}$ added, before $\mathrm{NH}_{4}-\mathrm{N}$ in the distillation was determined by filtrating with $1.00 \mathrm{ml} \mathrm{H}_{2} \mathrm{SO}_{4}$ using a $250 \mathrm{ml}$ burette and the percentage compositing content calculated [10].

Available phosphorus was determined following Murphy and Rikey method [11]. In which case, $5 \mathrm{ml}$ aliqof soil extract was pipetted into a $25 \mathrm{ml}$ volumetric flask and $10 \mathrm{ml}$ of distilled water added, then, $4 \mathrm{ml}$ of dissolved ascorbic acid added and left for 15 minutes for the development of colour as indication of phosphorus content in solution and this was determined using spectrophotometers $882 \mathrm{~mm}$. The flame photometer method was used to determine the amount of exchangeable sodium and potassium as outlined by [10] while exchangeable magnesium was determined on an Atomic Absorption Spectrophotometer as outlined by [12] Available sulphate was determined by estimating the sulphate concentration $\left(\mathrm{SO}_{4}\right)$ available in the soil samples as outlined by [13].

\section{Results and Discussion}

Values of soil $\mathrm{pH}$ in both locations showed that Ogbole Ogume grassland soils showed $5.37 \pm 0.31$ while Abbi grassland soils stood at $5.80 \pm 029$ with coefficient of variation of 0.06 and 0.05 , (Table 2) respectively. This clearly showed that the soils were acidic in nature. This was in agreement with the works of some researchers $[1,3,11,14]$. The lower $\mathrm{pH}$ values at Ogbole Ogume grassland soils as compared to Abbi grassland soils could be due to local soil management measures adopted by the people [15] owing to variations in their local subsistence farming practices. Furthermore, results in this study agreed with those of [3] who opined that higher cation exchange capacity usually causes a corresponding decrease in $\mathrm{pH}$ value.

Magnesium content was found to vary between $(1.37 \pm 1.73) \mathrm{mg} / 100 \mathrm{~g}$ and $(2.77 \pm 0.62) \mathrm{mg} / 100 \mathrm{~g}$ at Ogbole Ogume and Abbi grassland soils, respectively (Table 2). The presence of magnesium in Abbi in excess of about 202\% as compared to Ogbole Ogume could either be due to impact of cultivation [15] or such grassland soils contained some magnesium-bearing minerals like dolomite and chlorite [16]. However, further studies are needed to properly confirm this opinion. In addition, it has been stressed that $\mathrm{Ca} / \mathrm{Mg}$ and $\mathrm{K} / \mathrm{Mg}$ ratios were limiting factors to magnesium availability in plant nutrition, hence, we found that at both study sites, $\mathrm{Ca} / \mathrm{Mg}$ ratios were at ratio 2:1 [Ibid, 16]. This ratio could be beneficial to most plants growing within the study area since ratios of $1: 1$ to $5: 1$ are deemed to have beneficial effects in plants during nutrition [16].

Table 2. Values of the Physico-Chemical Characteristics of Sampled Soils.

\begin{tabular}{|c|c|c|c|c|c|c|c|c|c|c|c|c|c|c|}
\hline S/No & Location & $\mathrm{Ca}$ & Mg & $\mathrm{Na}$ & $\mathbf{K}$ & EC & CEC & $\mathrm{SO}_{4}$ & P/ppm & $\% \mathrm{~N}$ & pH & \%Clay & \%Silt & $\%$ Sand \\
\hline 1. & Ogume-A & 2.40 & 1.60 & 0.38 & 0.10 & 1.60 & 6.08 & 0.009 & 15.07 & 0.23 & 5.1 & 2.6 & 2.9 & 94.50 \\
\hline 2. & Ogume-B & 2.32 & 1.50 & 0.41 & 0.10 & 1.20 & 5.53 & 0.010 & 16.79 & 0.20 & 5.8 & 2.6 & 4.4 & 93.00 \\
\hline 3. & Ogume-C & 2.00 & 1.00 & 0.44 & 0.13 & 1.30 & 4.87 & 0.010 & 25.13 & 0.15 & 5.2 & 2.6 & 4.4 & 93.00 \\
\hline 5. & Abbi-B & 3.12 & 2.60 & 0.32 & 0.12 & 1.60 & 7.76 & 0.011 & 12.81 & 0.25 & 5.4 & 2.6 & 4.4 & 93.00 \\
\hline 6. & Abbi-C & 5.12 & 2.10 & 0.29 & 0.21 & 0.80 & 8.52 & 0.009 & 26.69 & 0.24 & 5.9 & 2.6 & 7.4 & 90.00 \\
\hline
\end{tabular}

On the other hand, we found that the $\mathrm{K} / \mathrm{Mg}$ ratios for both grassland soils of Ogbole Ogume and Abbi were 1:13 and $1: 15$, respectively. Results recorded in this present study agreed with the position taken by an earlier study which stated that more and more soils have $\mathrm{K} / \mathrm{Mg}$ ratios that are over 2:1, though, that such ratios have tendencies of leading to reduced up-take of magnesium in some plants [16].

Table 3. Mean and Ranges of the Physico-Chemical Characteristics of Sampled Soils.

\begin{tabular}{|c|c|c|c|c|c|c|c|c|c|c|c|c|c|c|c|}
\hline S/No & Location & Variable & $\mathrm{Ca}$ & Mg & $\mathbf{N a}$ & $\mathbf{K}$ & EC & CEC & $\mathrm{So}_{4}$ & P/ppm & $\% \mathrm{~N}$ & pH & \%Clay & \%Silt & $\%$ Sand \\
\hline 1 & Ogume & Range & 0.40 & 0.60 & 0.06 & 0.03 & 0.40 & 1.21 & 0.001 & 10.06 & 0.08 & 0.70 & 0.00 & 1.50 & 1.50 \\
\hline 2 & Ogume & Mean & 2.24 & 1.37 & 0.41 & 0.11 & 1.37 & 5.49 & 0.010 & 19.00 & 0.19 & 5.37 & 2.60 & 3.90 & 93.50 \\
\hline 3 & Abbi & Range & 4.16 & 1.50 & 0.13 & 0.09 & 1.30 & 4.04 & 0.002 & 19.55 & 0.05 & 0.70 & 0.00 & 3.00 & 3.00 \\
\hline
\end{tabular}

Thus, magnesium up-take in both study sites was found to be greatly limited with respect to availability average. Calcium contents of soils of both study sites were $2.24 \pm 0.17$ and $5.17 \pm 170 \mathrm{mc} / 100 \mathrm{~g}$ at grassland soils of Ogbole Ogume and Abbi respectively (Table 2). In a related study, it was reported that exchangeable calcium content in the soil of Jammu and Kashmir in India varied from 1.73 to $13.30 \mathrm{mc} / 100 \mathrm{~g}$ [17]. Hence, it could be said that the grassland soils of both Ogbole Ogume and Abbi fell within a healthy range as at the time of this investigative study. Sodium is generally regarded as an essential nutrient for plants owing to its involvement in regeneration of phosphoenolpyruvate in C4 plants [3]. Potassium is a very important plant nutrient because the growth of plants is hampered in its absence. Both study sites were found to contain averagely $0.11 \pm 0.01$ and $0.18 \pm 0.04 \mathrm{me} / 100 \mathrm{~g}$ of potassium, respectively at grassland soils of Ogbole Ogume and Abbi (Table 2). The closeness in the values of potassium between both studied sites could be due to similarities in edaphic factors between both sites. The potassium values recorded in this present study could be said to be healthy for the soils as they could allow for adequate potassium to magnesium binding, thereby ensuring adequate 
availability of the exchangeable metals for proper plant nutrition.

Electrical conductivities were found to be averagely $1.37 \pm 0.17 \mathrm{us} / \mathrm{cm}$ and $0.90 \pm 0.54 \mathrm{us} / \mathrm{cm}$ at Ogbole Ogume and Abbi grassland soils (Table 2). Higher values of electrical conductivity at Ogbole Ogume as compared to Abbi grassland soils could be attributable to the presence of higher concentrations of exchangeable ions in the soil solution. Low electrical conductivity could be due to leaching and poor drainage [18]. The cation exchange capacity for Ogbole Ogume grassland soils was found to be $5.49 \pm 0.05 \mathrm{me} / 100 \mathrm{~g}$ and $9.36 \pm 1.75 \mathrm{me} / 100 \mathrm{~g}$ at Abbi grassland soils (Table 2). The over $40 \%$ difference in CEC value between both study sites could be attributable to differences in impacts of anthropogenic activities between the 2 study sites. While investigating soil management methods under rice cultivation in Ndokwa grassland (of which the present study site is located), it was observed that CEC increased with the introduction of soil management measures in grassland soils of Ogbe Ogume, Utagba-Uno and Ossissa, respectively [15]. Thus, the increase in CEC at Abbi grassland soils where cultivation was found to be predominantly going on could be attributable to unique local soil management measures adopted by the farmers within the study area to increase crop productivity.

Table 4. Standard Deviation and Coefficient of Variation of the PhysicoChemical Characteristics of Sampled Soils.

\begin{tabular}{llllll}
\hline \multirow{2}{*}{ S/No. } & Properties & \multicolumn{2}{l}{ Standard Deviation } & \multicolumn{2}{l}{ Coefficient of Variation } \\
\cline { 2 - 6 } & Properties & Ogume & Abbi & Ogume & Abbi \\
\hline 1 & $\mathrm{pH}$ & 0.31 & 0.29 & 0.06 & 0.05 \\
2 & $\mathrm{Mg}$ & 1.73 & 0.62 & 01.26 & 0.22 \\
3 & $\mathrm{Ca}$ & 0.17 & 1.70 & 0.08 & 0.33 \\
4 & $\mathrm{Na}$ & 0.01 & 0.06 & 0.27 & 0.18 \\
5 & $\mathrm{~K}$ & 0.01 & 0.04 & 0.09 & 0.22 \\
6 & $\mathrm{EC}$ & 0.17 & 0.54 & 0.12 & 0.60 \\
7 & $\mathrm{CEC}$ & 0.50 & 1.75 & 0.09 & 0.19 \\
8 & $\mathrm{SO}_{4}$ & 0.001 & 0.001 & 0.1 & 0.1 \\
9 & $\mathrm{P} / \mathrm{ppm}$ & 4.39 & 8.21 & 0.23 & 0.34 \\
10 & $\% \mathrm{~N}$ & 0.03 & 0.02 & 0.16 & 0.08 \\
11 & $\mathrm{Clay}$ & 0.00 & 0.00 & 0.00 & 0.00 \\
12 & $\mathrm{Silt}$ & 0.71 & 0.82 & 0.18 & 0.14 \\
13 & Sand & 0.71 & 1.25 & 0.01 & 0.01 \\
\hline
\end{tabular}

Sulphates are important necessities for the survival of plants. They are important constituents of some amino acids, e.g. Cystein, which helps in forming plant proteins and without it, leaves of plants could become chlorotic and the stem slender [19]. In grassland soils of Ogbole Ogume, average sulphate was found to be $0.01 \pm 0.001 \mu \mathrm{g} / \mathrm{g}$ while in those of Abbi grassland soils, it was found to be $0.01 \pm 0.01 \mu \mathrm{g} / \mathrm{g}$, respectively (Table 2 ). The values shown in this present study indicated relatively low amounts of sulphates in grassland soils. In another instance, grassland soils at Abbi were observed to show phosphate content that was $23.95 \pm 8.21 \mu \mathrm{g} / \mathrm{g}$ as compared to $19.00 \pm 4.39 \mu \mathrm{g} / \mathrm{g}$ at Ogbole Ogume grassland soils (Table 2). Higher phosphate content, vis-à-vis phosphorus at Abbi grassland soils as compared to Ogbole Ogume grassland soils could be attributable to the availability of higher amounts of organic matter in such soils [20]. This of course, should be primarily due to the use of phosphorus-containing fertilizers during crop cultivation. A good $\mathrm{P}: \mathrm{K}$ ratio discourages broad leaf weed infestation, causes increase in growth vigour and leaf brix with pasture doing well at 2:1 and other crops at 1:1 ratios [18], respectively. The values noticed in this present study agreed with conventional discoveries for most grassland soils that the higher the phosphorus content, the lower the amount of total nitrogen available in soils [21].

Total nitrogen content was observed to be $0.19 \pm 0.03$ in Ogbole Ogume grassland soils and $0.26 \pm 0.02$ in Abbi grassland soils (Table 2). These values fell within ranges opined by an earlier study where it was stated that the amount of nitrogen in soils varied from 0.09 to $0.21 \%$, worldwide [19]. Furthermore, another earlier study had opined that in edaphic grasslands caused by soil conditions, that total nitrogen is usually on the deficient side, thus, constitutes a limiting factor to crop growth [22]. This implies the need to help improve the nitrogen content of grassland soils. Thus, statement by earlier researchers that there was an improvement in total nitrogen content of the grassland soils of Ogbe Ogume, Utagba-Uno and Ossissa with good soil management practices under rice cultivation as compared to areas where such management practices were not carried out [15], were in line.

The soil structure analyses showed that average clay content of both study sites was $2.60 \mathrm{~g}$; silt was $3.90 \pm 0.71$ at Ogbole Ogume grassland soils and 6.07 \pm 0.82 at Abbi grassland soils while sand was $93.50 \pm 0.71$ at Ogbole Ogume grassland soils and $91.33 \pm 0.25$ at Abbi grassland soils respectively (Table 2). The values obtained in this study were in agreement with the fact that grassland soils are usually sandy-loam in nature [23].

\section{Conclusion}

Analyses carried out in this present study has shown that soil types in grasslands of both study areas conformed to those of global soils through being predominantly composed of sandy-loam soils that were acidic in nature.

In addition, physico-chemical analyses conducted at both study sites in this study showed that both study sites exhibited comparable values, with similarities and differences recorded between both sites, in some instances. It was found that the values were in tandem with results obtained elsewhere in the globe. At the end, we were able to establish that the differences in values noticed for the analysed physico-chemical characteristics between both sites could be due to differences in use to which the grassland soils were subjected to. Thus, cultivation in Abbi grassland soils must have contributed significantly to increasing the values for soil $\mathrm{pH}$, magnesium, calcium, potassium, cation exchange capacity, phosphorus and nitrogen. This implied that soil use type could impact on the physico-chemical properties of grassland soils. The sandy content of both study sites were found to be the same at 
$30 \mathrm{~m}$ into the grasslands where there were no much anthropogenic influences as compared to the margin $(0 \mathrm{~m})$ and $10 \mathrm{~m}$ away from the end of both study sites where significant differences were observed.

\section{References}

[1] Janssens, F., A. Peter, J. Tallowin, P. Bakker, M. Bekker, F. Fillat and J. Oomes (1998) Relationship between Soil Chemical factors and Grassland diversity. Plant Soil Science. 202: 69-78.

[2] Paz, A. and J. Guerif (1993) Propidades fisicas y Mecanicas a escala Textural de Suelos con cantidades limitades de Materials hinchables. Invest. Agr. Prod-Prod Veg. 8: 387-410.

[3] Ashraf, M., G. A., Bhat, I. Y. Dar and M. Ali (2012) PhysicoChemical Characteristics of the Grassland Soils of Yusmarg Hill Resort (Kashmir, India). Ecologia Balkanica. 4 (1): 3138.

[4] Smith, J. (2010) Reams Soil Report and Results-kg/ha. Bio Services Soil Testing Laboratory, Pacroa. p. 1.

[5] Charles, W. (2002) Californian Grasslands. California Academy of Science. 92: 151-161.

[6] Obi, A. (2002) Introductory Plant Biology. Mindox publishing Company, Benin City, Nigeria. 145-150.

[7] Obadoni, B. O., N. E. Edema, H. Erheni, E. Ogie-Odia and O. Amukali (2009) A Checklist of the Flora of Edaphic Grasslands in the Rainforest Belts of Edo and Delta States of Nigeria. World Rural Observations. 1 (1): 43-49.

[8] Vermeer, J. G. and F. Berendse (1983) The Relationship between Nutrient Availability, Shoot Biomass and Species richness in Grassland and Wetland Communities. Vegetation. 53: 121-126.

[9] Bouyoucos, G. H. (1951) A Recalibration of the Hydrometer for making Mechanical Analysis of Soil. Agronomy Journal. 43: 434-438.

[10] Black, C. A. (1965) Bulk Density in C. A. Madison (eds) Methods of Soil Analysis. American Society of Agronomy. 374-390.
[11] Watanabe, F. S and S. R. Olsen (1965) Test of an Ascorbic Acid Method for determining Phosphorus in Water and $\mathrm{NaHCO}_{3}$ extracts from Soils. Soil Science Society of America. 29: $677-678$.

[12] Robert, Z. and F. Margaret (2001) Colorado Praire Grassland. California Academy of Science. 30: 100-120.

[13] Fox, R. L., R. A. Olsea, and H. F. Roades (1964) Evaluating the Sulphur status of Soils by Plant and Soil tests. Soil Science of America. 28: 243-246.

[14] Parkin Elmer Corp. (1968) Analytical Procedures for Atomic Absorption Spectrometry. Perkin Elmer Corp. Norwalk.

[15] Efe, S. I. and P. P. Ugboma (2011) Soil Management Methods under Rice Cultivation in Ndokwa Grassland Soils of Delta State, Nigeria. African Research Review. 5 (5): 251-263.

[16] Nye, P. H. and D. J. Greenland (1960) The Soil under Shifting Cultivation. Technical Communication No. 51. Commonwealth Agricultural Bureau, England.

[17] Gupta, R. D., K. K. Jha and B. P. Sahi (1980) Studies on Soil Physico-Chemical and Mineralogical Nature of Soils of Jammu and Kashmir. Current Agriculture. 4: 133-144.

[18] Kay, B. D. (1990) Rates of Change of Soil Structure under different Cropping systems. In: B. A. Stewart (ed), Advances in Soils Science. Springer Verlag Inc., New York. Pp. 1-52.

[19] Dutta, A. C. and T. C. Dutta (2008) Botany for Degree Students. Oxford University Press, New Delhi. Pp. 220-233.

[20] Miodrag, D. J., M. K. Nikola and B. A. Svetlana (2003) The Availability of Base Elements $(\mathrm{Ca}, \mathrm{Mg}, \mathrm{Na}, \mathrm{K})$ in some Important Soil Types in Serbia. Proceedings for Natural Sciences, Matica Srpska NoviSad. 104: 11-21.

[21] Katti, V. M. and J. S. Rao (1979) Chemical Characteristics of some Salt affected Soils in Ghata Prabha left Bank area, Karnataka. Madras Agricultural Journal. 66: 192-194.

[22] Okpor, O. M. (2002) Evaluation of the Fertility of Hydromorphic Soils under Yam (Dioscorea Rotundata) Cultivation in the Lower Niger Valley.

[23] Miller, R. W. and R. L. Donahue (2011) Soils in our Environment. Seventh edition. Prentice Hall, Upper River, New Jersey. 